\title{
A Novel Postsynaptic Mechanism for Heterosynaptic Sharing of Short-Term Plasticity
}

\author{
Kathryn J. Reissner, ${ }^{1}$ Lu Pu, ${ }^{1}$ Joanna H. Schaffhausen, ${ }^{3}$ Heather D. Boyle, ${ }^{1}$ Ian F. Smith, ${ }^{1}$ Ian Parker, ${ }^{1}$ \\ and Thomas J. Carew ${ }^{1,2}$ \\ ${ }^{1}$ Department of Neurobiology and Behavior and ${ }^{2}$ Center for the Neurobiology of Learning and Memory, University of California, Irvine, Irvine, California \\ 92697, and ${ }^{3} \mathrm{ABC}$ News Medical Unit, Needham, Massachusetts 02494
}

Postsynaptic release of $\mathrm{Ca}^{2+}$ from intracellular stores is an important means of cellular signaling that mediates numerous forms of synaptic plasticity. Previous studies have identified a postsynaptic intracellular $\mathrm{Ca}^{2+}$ requirement for a form of short-term plasticity, post-tetanic potentiation (PTP) at sensory neuron (SN)-motor neuron synapses in Aplysia. Here, we show that postsynaptic IP $_{3}{ }^{-}$ mediated $\mathrm{Ca}^{2+}$ release in response to a presynaptic tetanus in an SN that induces PTP can confer transient plasticity onto a neighboring SN synapse receiving subthreshold activation. This heterosynaptic sharing of plasticity represents a dynamic, short-term synaptic enhancement of synaptic inputs onto a common postsynaptic target. Heterosynaptic sharing is blocked by postsynaptic disruption of $\mathrm{Ca}^{2+}$ - and $\mathrm{IP}_{3}$-mediated signaling, and, conversely, it is mimicked by postsynaptic injection of nonhydrolyzable $\mathrm{IP}_{3}$, and by photolysis of caged $\mathrm{IP}_{3}$ in the MN. The molecular mechanism for heterosynaptic sharing involves metabotropic glutamate receptors and Homerdependent interactions, indicating that Homer can facilitate the integration of $\mathrm{Ca}^{2+}$-dependent plasticity at neighboring postsynaptic sites and provides a postsynaptic mechanism for the spread of plasticity induced by presynaptic activation. Our results support a model in which postsynaptic summation of $\mathrm{IP}_{3}$ signals from suprathreshold and subthreshold inputs results in molecular coincidence detection that gives rise to a novel form of heterosynaptic plasticity.

\section{Introduction}

Synaptic plasticity exists in a wide range of temporal domains. Activity-dependent short-term plasticity, lasting on the order of seconds to minutes, includes paired-pulse facilitation, pairedpulse depression, and post-tetanic potentiation (PTP). Whereas long-lasting forms of plasticity, such as long-term potentiation (LTP) and long-term depression (LTD), are generally considered to provide a means of information storage in neurons, these short-term forms of plasticity are critical for dynamic, momentto-moment adjustments of synaptic strength during online processing of neural information. At most synapses, PTP is typically thought to be mediated solely by presynaptic mechanisms (Zucker and Regehr, 2002). However, a major component of PTP at sensory neuron-motor neuron (SN-MN) synapses in Aplysia requires postsynaptic $\mathrm{Ca}^{2+}$ (Bao et al., 1997; Schaffhausen et al., 2001; Jin and Hawkins, 2003). The fact that postsynaptic $\mathrm{Ca}^{2+}$ contributes significantly to PTP at SN-MN synapses in Aplysia led us to propose that the induction of PTP at one synapse might transiently facilitate induction of plasticity at neighboring synapses onto the same $\mathrm{MN}$ via shared postsynaptic $\mathrm{Ca}^{2+}{ }_{-}$ dependent mechanisms (Schaffhausen et al., 2001). Here, we

Received Sept. 25, 2009; revised March 16, 2010; accepted April 12, 2010.

This work was supported by National Institutes of Health Grant R01 MH14-10183 and National Science Foundation Grant IOB-0444762 (T.J.C.). We thank Kelsey Martin and Wayne Sossin for kind gifts of Aplysia SN and CNS libraries. We thank Thomas Fischer, John Guzowski, Michael Sutton, Robert Zucker, and members of the Carew laboratory for constructive comments on an earlier version of the manuscript.

Correspondence should be addressed to Thomas J. Carew at the above address. E-mail: tcarew@uci.edu.

DOI:10.1523/JNEUROSCI.4767-09.2010

Copyright $\odot 2010$ the authors $\quad 0270-6474 / 10 / 308797-10 \$ 15.00 / 0$ show that heterosynaptic sharing of PTP can indeed occur when an input sufficient for PTP induction (20 Hz activation of an SN) is paired with a subthreshold input to a neighboring SN (activated at $7 \mathrm{~Hz}$ ). The mechanism for heterosynaptic sharing is dependent upon postsynaptic $\mathrm{Ca}^{2+}$ - and Homer-mediated interactions. Heterosynaptic sharing is blocked by postsynaptic injection of BAPTA, as well as inhibitors of intracellular $\mathrm{Ca}^{2+}$ release, including heparin, thapsigargin, and caffeine. Moreover, heterosynaptic sharing is facilitated by postsynaptic injection of nonhydrolyzable $\mathrm{IP}_{3}$ and by photoactivated caged $\mathrm{IP}_{3}$. Finally, heterosynaptic sharing is blocked by disruption of Homermediated protein interactions following postsynaptic injection of a synthetic peptide containing the Homer binding sequence of the Aplysia $\mathrm{IP}_{3}$ receptor $\left(\mathrm{IP}_{3} \mathrm{R}\right)$.

These findings provide evidence for a novel form of shortterm heterosynaptic plasticity that arises from postsynaptic interactions between presynaptic inputs, and indicates that activity-dependent spread of plasticity is not limited to the long-term time domains. Moreover, this unique form of plasticity provides a mechanism for dynamic, temporally restricted amplification of synaptic inputs onto a common postsynaptic target.

\section{Materials and Methods}

General methods. Wild-caught Aplysia californica (120-250 g) were obtained commercially (Marinus). Animals were anesthetized by injection of isotonic $\mathrm{MgCl}_{2}$, and isolated ganglia were pinned and desheathed in dishes containing 1:1 $\mathrm{MgCl}_{2}$ /artificial seawater (ASW) (containing, in mM: $460 \mathrm{NaCl}, 55 \mathrm{MgCl}_{2}, 11 \mathrm{CaCl}_{2} 10 \mathrm{KCl}$, and 10 Tris, $\mathrm{pH} 7.6$ ).

Protein quantification was performed using the BCA Protein Assay (Pierce). Western blots were performed by electrophoresis using the 
Invitrogen NuPAGE gel system. Blotting conditions were varied depending on primary antibody used. Blocking was performed in 3\% Blotto in TBS with $0.1 \%$ Tween 20, and blots were probed overnight in primary antibody in blocking solution, followed by $1 \mathrm{~h}$ at room temperature in HRP-conjugated secondary antibody at 1:2500. Blots were developed using the ECL Western Blotting Analysis System by GE Healthcare.

Cloning. For use in degenerate reverse transcriptase (RT)-PCR, whole RNA was prepared from pleural and pedal ganglia using Trizol Reagent (Invitrogen). Initial forward and reverse degenerate Homer primer sequences were CAYGTNTTYCANATHGAYCC and CCAYTGNCCRAAMTTYTG, respectively. Subsequent RT-PCR was performed using a separate degenerate forward primer (ATGGGNGARCARTTYATHTT) and a gene-specific reverse primer from within the initially identified sequence. PCR was then performed on Aplysia sensory neuron or CNS libraries [generously provided by Kelsey Martin (University of California, Los Angeles, CA) and Wayne Sossin (McGill University, Montreal, Canada), respectively] with different combinations of forward gene-specific primers and $\mathrm{T} 3$ or $\mathrm{T} 7$ vector primers. Typically, PCR products were cloned into the Invitrogen pCR2.1 sequencing vector and submitted for DNA sequencing (Laguna Scientific). This approach yielded a total of 353 aa. While a termination codon was not identified within the library screen, alignment of ApHomer with Drosophila and vertebrate Homers indicated that the sequence obtained likely represented $>95 \%$ of the coding region of ApHomer. The translation start site was confirmed using $5^{\prime}$ rapid amplification of cDNA ends with the GeneRacer kit from Invitrogen, using pleural/pedal RNA as starting material.

Cloning of the $\mathrm{IP}_{3}$ receptor in Aplysia was performed by degenerate RT-PCR from pleural/pedal ganglia and PCR of an Aplysia CNS library using gene-specific and vector primers, as described for ApHomer. Initial degenerate forward and reverse primers were CCICCNAARAARTTYMG and AAWTTYTCYTGYTCNGCRTG. DNA sequence obtained from the initial fragment of Aplysia cDNA was used to make gene-specific primers, which were then coupled to vector primers for use in amplification from the Aplysia CNS library. For expression in bacteria, the first 258 aa of $\mathrm{ApIP}_{3} \mathrm{R}$ were cloned into the pENTR vector from Invitrogen. Following recombination into the pDEST15 glutathione $S$-transferase (GST) expression vector, recombinant protein was expressed in BL21(DE3)Star cells. Bacterial pellets were resuspended in lysis buffer (PBS + 0.5\% Triton X-100, 10\% glycerol, 10 mm imidizole) and sonicated. Soluble protein was recovered by centrifugation and coupled to glutathione agarose (Pierce). Constructs for the expression of recombinant ApHomer were prepared using the EcoRI and NotI sites in the pGEX4T-3 vector (GE Healthcare), containing either amino acids 1-335 or 163-335. Following expression, bacterial cell pellets were resuspended and lysed by sonication in a smiliar fashion. The accuracy of all constructs was confirmed by DNA sequencing (Laguna Scientific, Cogenics).

Tissue distribution and ApHomer expression. Regulation of Homer expression was investigated using four separate methods: injury, in vivo 5-HT, $\mathrm{KCl}$ depolarization, and tailshock. To look at the effect of injury,
A2
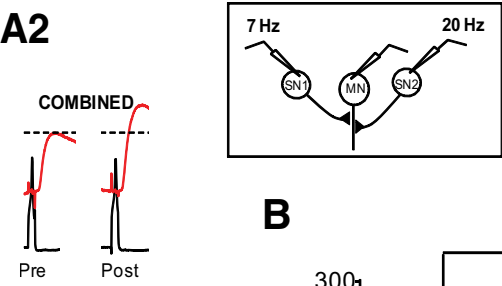

B

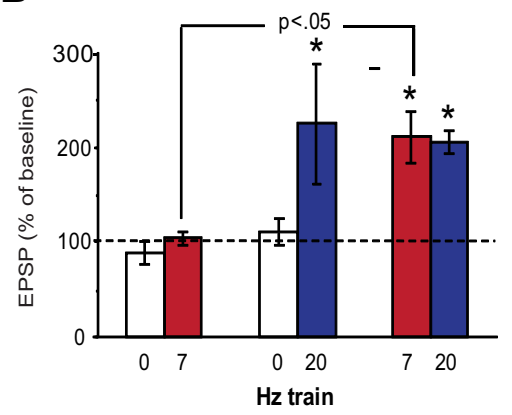

D

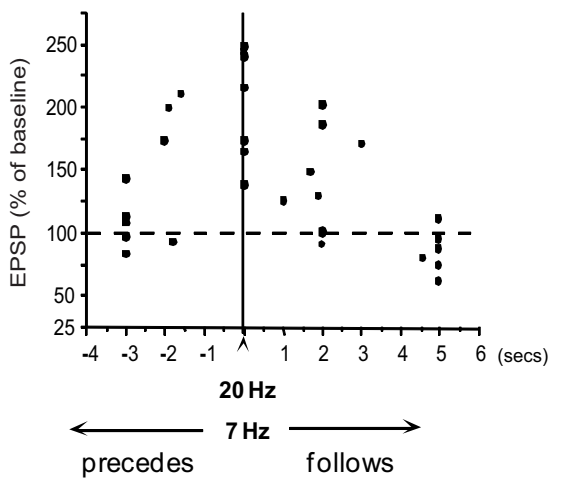

Figure 1. Induction of PTP can be shared with a neighboring synapse receiving subthreshold activation. $A$, Inset, Experimental design: two presynaptic SNs are identified that synapse onto the same postsynaptic MN. The 20 and $7 \mathrm{~Hz}$ trains are delivered intracellularly to the two SNs, while postsynaptic EPSPs are recorded in the MN. Representative traces are shown from synapses receiving $7 \mathrm{~Hz}$ alone (A1, top left), $20 \mathrm{~Hz}$ alone (A1, bottom left), or $7 \mathrm{~Hz}$ paired with $20 \mathrm{~Hz}$ ( $\boldsymbol{A} \mathbf{2}$, top and bottom, respectively). $B$, Histogram of results indicating that an $\mathrm{SN}$ receiving a $7 \mathrm{~Hz}$ train acquires the ability to induce heterosynaptic sharing, but only when paired with a $20 \mathrm{~Hz}$ train to a neighboring SN. Previously, we have shown that small synapses $(<6.2 \mathrm{mV})$ exhibit an enhanced form of PTP, which is more robust than the magnitude of PTP observed across synapses of all sizes ( 160 vs $285 \%)$ (Schaffhausen et al., 2001). Here, we observed a similar result, in which $20 \mathrm{~Hz}$ PTP varied from $\sim 200 \%$, when tested among small 列 7). Interestingly, the magnitude of the shared $7 \mathrm{~Hz}$ PTP is consistently $\sim 200 \%$, regardless of the degree of potentiation at the "donor" SN. ${ }^{*} p<0.05, n=4-7$ per group. C, Top, schematic diagram of experimental protocol. Pretests of both SNs are taken typically made $10 \mathrm{~s}$ after the offset of the trains (e.g., as in $2 B$ ). For time course experiments, a single post-test measurement was ade for each synapse at $1 \mathrm{~s}, 1 \mathrm{~min}$, or $10 \mathrm{~min}$ after the overlapping trains. As shown in C (bottom), while $20 \mathrm{~Hz}$ PTP remains significantly above baseline at $10 \mathrm{~min}$, the shared $7 \mathrm{~Hz}$ PTP is no longer significantly above baseline by $1 \mathrm{~min}$ ( $n=4-7$ per group). D, Sharing of PTP requires that the 7 and $20 \mathrm{~Hz}$ trains must occur within a narrow time window.

the animal was anesthetized, and the pleural and pedal ganglia were immediately excised into Trizol for RNA preparation. One hour later, the other half was removed and processed identically. For in vivo 5-HT treatment, animals were placed in $6 \mathrm{~L}$ of ASW or $6 \mathrm{~L}$ of ASW containing 250 $\mu \mathrm{M} 5$-HT for $1.5 \mathrm{~h}$ at $18^{\circ} \mathrm{C}$. After $1.5 \mathrm{~h}$, animals were either taken for tissue or moved to ASW. Tailshock was performed as previously described (Sharma et al., 2003). Five shocks were given to one side of the tail with a 10 min intershock interval. The unshocked side served as a control to that animal. Pleural and pedal ganglia were dissected into Trizol. In all cases, reverse transcription was performed using $3.0 \mu \mathrm{g}$ of total RNA, and $1.0 \mu \mathrm{l}$ of cDNA was used in the PCR. Cycle number was optimized for each primer set, to ensure amplification was kept within the linear range for comparison between control and experimental groups. In all cases, histone $h 4$ was used as a negative control, and the immediate early gene 
clebp was used as a positive control. clebp has previously been demonstrated to be rapidly transcribed following injury and in vivo 5-HT exposure (Alberini et al., 1994). RT-PCR was also used to assess tissue distribution, similarly as described for investigation of experiencedependent expression of ApHomer.

Antibody preparation and detection of protein interactions. Frozen rat brains were obtained from Pel Freez Biologicals. Metabotropic glutamate receptor 1 (mGluR1) antibody was from $B D$ Biosciences, and $\mathrm{IP}_{3} \mathrm{R}$ antibody was from Affinity BioReagents. Recombinant ApHomer proteins were coupled to $0.1 \mathrm{ml}$ of packed glutathione-agarose overnight at $4^{\circ} \mathrm{C}$. As described by Tu et al. (1998), rat cerebellar extracts were prepared by sonication in PBS with $1 \%$ Triton X-100 (PBST) plus protease inhibitors, followed by centrifugation at $15,000 \times g$ for $10 \mathrm{~min}$. Glutathione beads were washed three times with $0.3 \mathrm{ml}$ of PBST plus protease inhibitors, and $40 \mathrm{mg}$ of cerebellar extract was allowed to bind for $4 \mathrm{~h}$ at $4^{\circ} \mathrm{C}$. Beads were again washed once with PBS followed by two additional washes with PBST, and bound material was removed by boiling in $100 \mu \mathrm{l}$ of SDSPAGE sample buffer. Equal amounts of eluted material were separated by gel electrophoresis for Western blotting with antibodies against mGluRla and type $1 \mathrm{IP}_{3} \mathrm{R}$.

In the case of recombinant GST-ApIP ${ }_{3} \mathrm{R}$, soluble proteins were similarly coupled to glutathione-agarose overnight at $4^{\circ} \mathrm{C}$. Ganglia from four to six animals were homogenized with a glass-Teflon, motor-driven homogenizer into $1.0-1.2 \mathrm{ml}$ of PBST plus a 1:100 Sigma mammalian protease inhibitor mixture, $3 \mathrm{~mm} \mathrm{Na}$ orthovanadate, and $30 \mathrm{~mm} \mathrm{NaF}$, and were centrifuged for $10 \mathrm{~min}$ at $10,000 \times \mathrm{g}$. A small amount of supernatant was saved for use as input material and then was divided equally for addition to agarose-coupled recombinant proteins. To inhibit the Homer- $\mathrm{IP}_{3} \mathrm{R}$ interaction, a synthetic peptide corresponding to Aplysia $\mathrm{IP}_{3} \mathrm{R}$ amino acids 41-52 (GDLNNPPKKFRD; mutant peptide GDLNNPLKKRRD) was synthesized by Invitrogen. Peptide was added to Aplysia CNS extract before addition of the extract to glutathione-coupled recombinant protein.

Following binding on a rotator for $4 \mathrm{~h}$ at $4^{\circ} \mathrm{C}$, unbound material was removed by three washes of PBST plus inhibitors. Bound material was eluted by addition of SDS-PAGE sample buffer and boiling for $5 \mathrm{~min}$, followed by analysis by Western blot for ApHomer. A custom affinitypurified ApHomer antibody was prepared by Covance Research Products against the ApHomer peptide,-LQDSQRQLQDGRSSRDQEHRE (amino acids 324-344). The synthetic peptide was conjugated to KLH and used as immunogen for antibody generation in rabbits.

Electrophysiology. For electrophysiology, pleural and pedal ganglia were desheathed in 1:1 isotonic $\mathrm{MgCl}_{2} / \mathrm{ASW}$ to expose the tail sensory and motor neuron clusters. $\mathrm{MgCl}_{2}$ was removed by perfusion of the preparation with ASW for at least 15 min. Intracellular recording was performed using glass microelectrodes containing $3 \mathrm{M} \mathrm{KCl}$ with electrode resistance of 8-12 $\mathrm{M} \Omega$. Motor neurons were hyperpolarized to approximately $-70 \mathrm{mV}$. The resting potential and input resistance of the $\mathrm{SN}$ and $\mathrm{MN}$ were monitored throughout each experiment. Baseline EPSP amplitudes were determined by injection of current to elicit a single test spike in the SN in each of the two presynaptic SNs ( $\sim 200 \mathrm{~ms}$ apart). One minute later, a tetanizing stimulus (generated by individual current pulses [ $10 \mathrm{nA}$ ] at 20 or $7 \mathrm{~Hz}$ for $2 \mathrm{~s}$ ) was applied to the SNs. A posttest EPSP was measured $10 \mathrm{~s}$ after the offset of the stimulus train. The $200 \mathrm{~mm}$ BAPTA (tetrapotassium salt, Invitrogen), $25 \mu \mathrm{M}$ heparin (Calbiochem), and $125 \mu \mathrm{M} \mathrm{IP}{ }_{3}$ were dissolved in $3 \mathrm{M} \mathrm{KCl}, 10 \mathrm{~mm}$ HEPES, and $3 \mathrm{~mm}$ Fast Green dye (Fisher Scientific). Drugs were injected into the MN with two to four pulses $(20 \mathrm{~ms}, 20-40 \mathrm{psi})$ from a picospritzer (General Valve), and at least $20 \mathrm{~min}$ were allowed for drugs to take effect before pretest values were obtained. For caffeine experiments, caffeine ( $5 \mathrm{~mm}$, Sigma) was dissolved in ASW and perfused over the ganglion through the experiment. Thapsigargin ( $5 \mu \mathrm{M}$, Sigma) was prepared in $0.1 \%$ DMSO and continually perfused as in the case of caffeine.

For mGluR1-blocking experiments, LY367385 (300 $\mu \mathrm{M})$ and S-MCPG $(500 \mu \mathrm{M})$ (Tocris Bioscience) were prepared in $110 \mathrm{~mm} \mathrm{NaOH}$ and diluted 1:250 in ASW immediately before each experiment. In vehicle control experiments, $200 \mu \mathrm{l}$ of $110 \mathrm{~mm} \mathrm{NaOH}$ was added to $50 \mathrm{ml}$ of ASW (1:250) and perfused in a similar manner as drug-treated preparations. Following removal of $\mathrm{MgCl}_{2}$ by perfusion, drug or vehicle was bath ap-
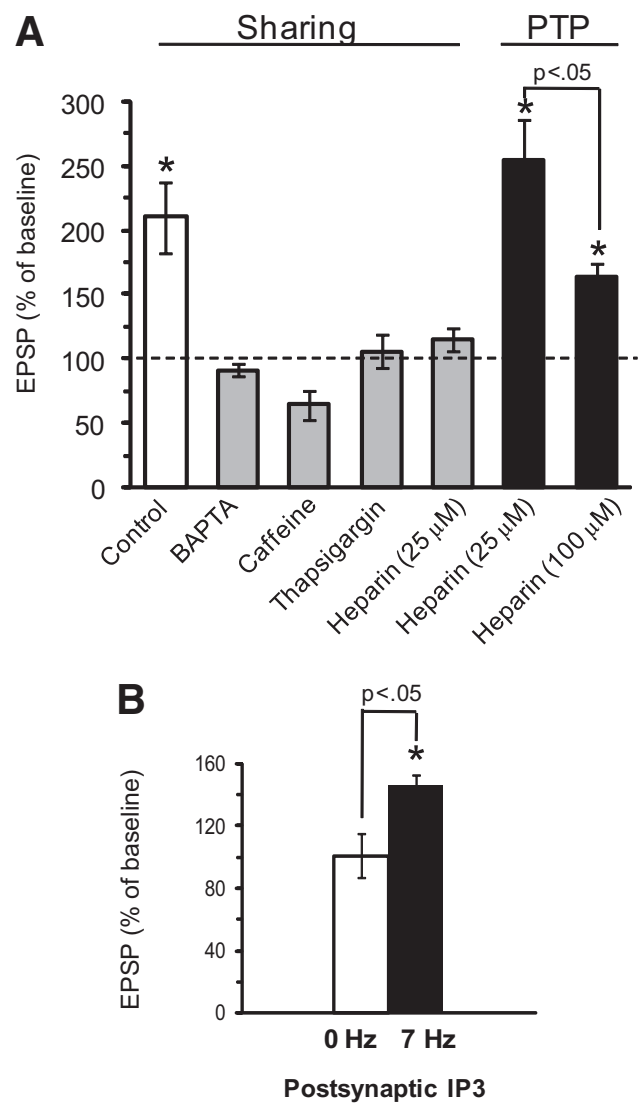

Figure 2. Heterosynaptic sharing requires postsynaptic intracellular calcium. $\boldsymbol{A}$, Degree of sharing (control, open bar, $n=7$ ) is significantly blocked in the presence of $\mathrm{Ca}^{2+}$ inhibitors BAPTA $(n=8)$, caffeine $(n=5)$, heparin $(n=7)$, and thapsigargin $(n=5)$. While $25 \mu \mathrm{m}$ heparin is sufficient to block sharing, that concentration is without effect on PTP (black bar, $n=$ 6). In contrast, $100 \mu \mathrm{m}$ heparin results in significant, attenuation of PTP $(n=4)$. ${ }^{*} p<0.05$, within-group comparison. $\boldsymbol{B}$, Injection of nondegradable $\mathrm{IP}_{3}$ into an $\mathrm{MN}$ has no effect on baseline synaptic transmission from an unstimulated $\mathrm{SN}(0 \mathrm{~Hz}$, open bar), but when paired with a 7 $\mathrm{Hz}$ train delivered to the SN results in significant PTP ( $n=7$ per group).

plied for at least $30 \mathrm{~min}$, at a flow rate of $0.5-1 \mathrm{ml} / \mathrm{min}$, before the commencement of recording.

Synthetic $\mathrm{ApIP}_{3} \mathrm{R}$ peptide (active and mutant) was prepared at a concentration of $1.0 \mathrm{~mm}$ in $0.5 \mathrm{~m} \mathrm{KOAc}, 10 \mathrm{~mm}$ TrisCl, pH 7.5, and $15 \mathrm{~mm}$ Fast Green dye $(\sim 1.0 \%)$. Peptides were injected into the MN by $28-32$ pulses, $10-40 \mathrm{~ms}$ each, at $20 \mathrm{psi}$. The number and duration of pulses was determined depending upon the resistance of injection electrode and the size of the cell. Following injection, cells were continually perfused in ASW for at least $45 \mathrm{~min}$ before recording from MN. Monosynaptic EPSPs were measured and PTP performed as described above. Short-term facilitation induced by a single pulse of 5-HT was also assessed following three pretests taken at $15 \mathrm{~min}$ intervals. Ten minutes after the last pretest, $50 \mu \mathrm{M} 5$-HT was perfused for $5 \mathrm{~min}$, and a single post-test was performed immediately.

Input resistance and excitability of the injected $\mathrm{MN}$ were monitored in all experiments, and any preparations that indicated possible cellular damage were discarded before onset of the stimulus train $(\sim 10 \%$ of cases).

Cell culture. Cell culture was performed based on a modified protocol as described previously (Gruenbaum and Carew, 1999; Lyles et al., 2006). Briefly, pleural and abdominal ganglia from 80 to $100 \mathrm{~g}$ of Aplysia were first incubated in $10 \mathrm{mg} / \mathrm{ml}$ Protease type IX (Sigma) at $34.5^{\circ} \mathrm{C}$ for $2 \mathrm{~h}$ and $15 \mathrm{~min}$ and $2 \mathrm{~h}$ and $10 \mathrm{~min}$, respectively. The ganglia were then desheathed. SNs were isolated from the pleural ganglia, and LFS MNs were isolated from the abdominal ganglia. Identified SNs or MNs were then plated in culture dishes. The sensory neuron processes were carefully manipulated to contact the motor neurons. Culture dishes 
were precoated with poly-L-lysine $(0.5 \mathrm{mg} / \mathrm{ml})$. Culture medium consisted of 50\% Aplysia hemolymph and 50\% L-15 medium supplemented with salts $\left(\mathrm{NaCl}, 260 \mathrm{~mm}\right.$; $\mathrm{CaCl}_{2}, 10$ mм; $\mathrm{KCl}, 4.6$ mм; $\mathrm{MgSO}_{4}, 25 \mathrm{~mm} ; \mathrm{MgCl}_{2}, 28$ $\mathrm{mm} ; \mathrm{NaHCO}_{3}, 2 \mathrm{~mm}$; HEPES, $15 \mathrm{~mm}$ ) and D-glucose (34.6 mm). Additionally, glutamine $(2 \mathrm{~mm})$, penicillin $(100 \mathrm{U} / \mathrm{ml})$, and streptomycin $(100 \mathrm{U} / \mathrm{ml})$ were also included in the culture medium. Cultured cells were left on the microscope stage overnight and then transferred to an $18^{\circ} \mathrm{C}$ incubator. After $4 \mathrm{~d}, \mathrm{Ca}^{2+}$ imaging was performed on MNs, and synaptic strengths between the $\mathrm{SN}-\mathrm{MN}$ cocultures were measured. Electrophysiological recordings were performed similarly to those in the intact CNS.

Photolysis of caged $\mathrm{IP}_{3}$ and calcium imaging in MN neurites. Cultured MNs were injected with $1 \mathrm{~mm}$ caged $\mathrm{IP}_{3}$ (Invitrogen) and $10 \mathrm{~mm}$ cellimpermeable Fluo- $4 \mathrm{Ca}^{2+}$ indicator dye (Invitrogen) using a picospritzer, similar to the microinjection procedure described in the intact ganglia. To aid visualization of calcium release in MN neurites, cells were pretreated with a high-K ${ }^{+}(100 \mathrm{~mm})$, high-calcium (55 mm), and low-magnesium (11 mM) ASW for $5 \mathrm{~min}$ (Malkinson and Spira, 2010). This conditioning depolarization loads intracellular calcium stores (Garaschuk et al., 1997; Hong and Ross, 2007). Imaging was accomplished using a custom-built microscope system based around an Olympus IX 50 microscope equipped with an Olympus $60 \times$ oil objective lens (numerical aperture, 1.45), using excitation by a solid-state $488 \mathrm{~nm}$ laser (Spectra Physics sapphire) and imaging emitted fluorescence at $\lambda>510 \mathrm{~nm}$ using a Cascade 650 electron-multiplied CCD camera (Roper Scientific).

Fluorescence signals are expressed as ratios $\left(F / F_{0}\right.$ or $\left.\Delta F / F_{0}\right)$ of the fluorescence $(F)$ at each pixel relative to the mean resting fluorescence $\left(F_{0}\right)$ before stimulation. $\mathrm{IP}_{3}$ was photoreleased from a caged precursor by delivering flashes of UV light (350-400 $\mathrm{nm}$ ) focused uniformly throughout the field of view. Image data were streamed to computer memory and then stored on disc for offline analysis using the MetaMorph software package (Molecular Dynamics).

Photolysis of caged $I_{3}$ and electrophysiology in $S N-M N$ coculture. The electrophysiological studies using SN-MN cocultures were performed on a different experimental setup than that used to visualize $\mathrm{Ca}^{2+}$ transients in neurites (as described above). Following microinjection with caged $\mathrm{IP}_{3}$ and fluo-4, cultured cells were again subject to a conditioning depolarization by treatment with a high $\mathrm{K}^{+}(100 \mathrm{~mm})$ ASW for $5 \mathrm{~min}$ to load intracellular $\mathrm{Ca}^{2+}$ stores and then subject to a $2 \mathrm{~s} \mathrm{UV} \mathrm{flash.} \mathrm{This} \mathrm{condi-}$ tioning depolarization pretreatment, followed by washout, had no effect on subsequent baseline synaptic transmission. Flashes of UV light were derived from a Zeiss Xite 120 metal halide light source via a UV filter set in a Zeiss Axiovert 200 inverted microscope (Leissring et al., 1999) and were delivered to the $\mathrm{MN}$ soma and proximal neurites.

EPSPs of sensory-motor synapses before and after (1) $20 \mathrm{~Hz}$ stimuli, (2) $7 \mathrm{~Hz}$ stimuli, (3) $7 \mathrm{~Hz}$ stimuli paired with the UV flash, (4) UV flash alone, and (5) no stimulation were then compared.

Data analysis and statistics. Postsynaptic EPSP amplitudes were measured as the peak voltage of the EPSP. In the case of 5-HT-induced facilitation, baseline EPSP was determined based on the average of three pretests in ASW, and only EPSPs with pretests within $20 \%$ of the mean were used for further analysis. In the case of PTP, a single pretest was performed as described previously (Schaffhausen et al., 2001). All EPSP amplitudes are expressed as a percentage of the baseline mean. Twotailed $t$ tests were used for data analysis. All data are shown as \pm SEM.

\section{Results}

\section{PTP can be shared at $\mathrm{SN}-\mathrm{MN}$ synapses}

To directly test the hypothesis that convergent inputs might result in postsynaptic sharing of PTP, we first asked whether presynaptic activation of an $\mathrm{SN}$ at a level that is ineffective in producing PTP might gain the ability to induce PTP when paired with effective activation of a neighboring presynaptic SN. Intact ganglia (abdominal or pleural-pedal, in separate experiments) were excised, and neurons were impaled for intracellular recording. By eliciting a single presynaptic action potential and recording the evoked postsynaptic EPSP, two presynaptic SNs were identified that made synapses onto a common MN. At least 15 min after identification of convergent synapses, each SN was activated with a train ( $2 \mathrm{~s}$ in duration) of either $7 \mathrm{~Hz}$ (which produces no PTP) or $20 \mathrm{~Hz}$ (which induces PTP) (Fig. 1, inset). EPSPs were then measured $10 \mathrm{~s}$ after the offset of the trains. While $7 \mathrm{~Hz}$ alone produced no PTP, when paired with a $20 \mathrm{~Hz}$ train to the other $\mathrm{SN}$, the $7 \mathrm{~Hz}$ train induced a robust enhancement of synaptic strength (Fig. $1 A, B$ ). Additional experiments with no 
A

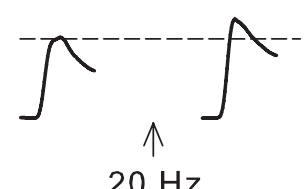

$20 \mathrm{~Hz}$
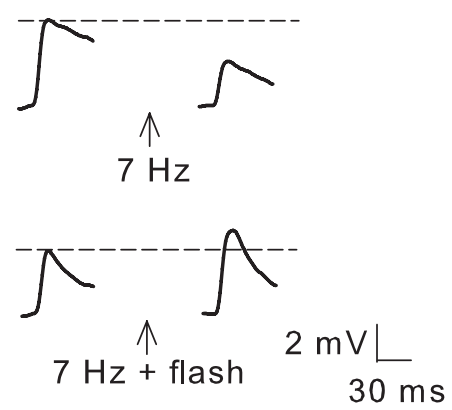

B

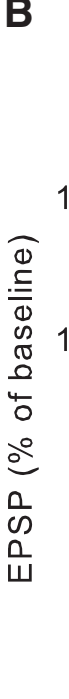

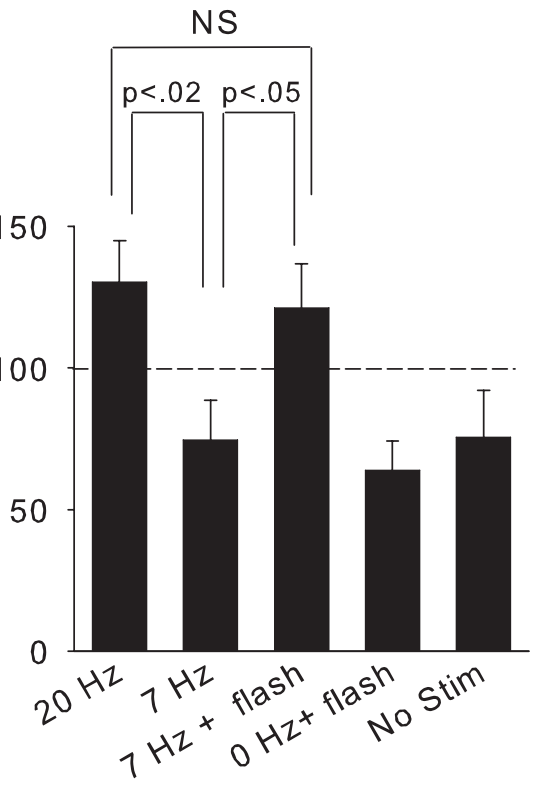

Figure 4. Sharing-like potentiation is induced by pairing $7 \mathrm{~Hz}$ activation with photolysis of caged IP. SN-MN pairs are cocultured. A 20 or $7 \mathrm{~Hz}$ train is delivered extracellularly to the $\mathrm{SN}$, while EPSPs are recorded in the MN. The MN is microinjected with caged $\mathrm{IP}_{3}$ and receives a UV flash (Fig. 3). $A$, Representative EPSPs are shown from SN-MN synapses before and after a $20 \mathrm{~Hz}$ train (top), a $7 \mathrm{~Hz}$ train alone (middle), or a $7 \mathrm{~Hz}$ train paired with a photolysis flash (bottom). $\boldsymbol{B}$, Summary histograms indicating that 7 $\mathrm{Hz}$ activation paired with the photolysis of caged $\mathrm{IP}_{3}$ in the postsynaptic $M N$ acquires the ability to induce potentiation comparable to a $20 \mathrm{~Hz}$ train. In contrast, $7 \mathrm{~Hz}$ activation alone or photolysis alone exhibits synaptic decrement comparable to unstimulated SN-MN pairs. $n=4-8$ in each group.
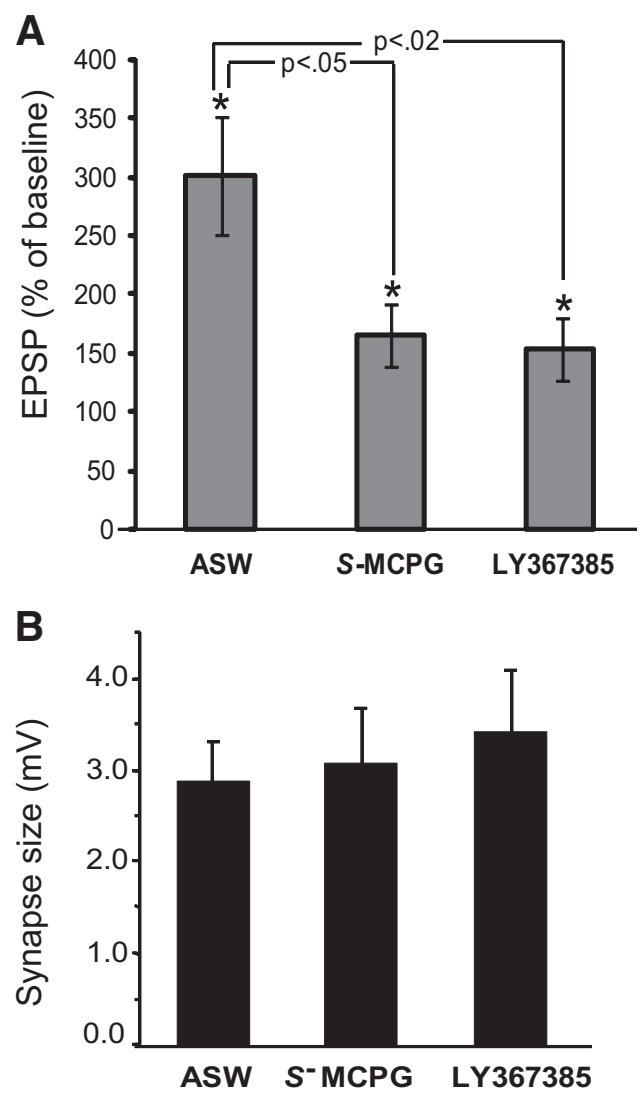

Figure 5. PTP in Aplysia requires type I mGluRs. $A$, PTP is significantly attenuated in the presence of mGluR inhibitors S-MCPG or LY367385 (ASW, $n=10$ per group; S-MCPG/LY367385, $n=7$ per group). ${ }^{*} p<0.05$, within-group comparison. $\boldsymbol{B}$, The blockers had no effect on synapse size ( $n=$ $7-10$ per group).

activation of one $\mathrm{SN}$ and $20 \mathrm{~Hz}$ activation of the other $\mathrm{SN}$ revealed that nonactivated synapses do not passively inherit this enhancement (Fig. $1 B$ ), indicating that the 7 $\mathrm{Hz}$ train likely generates a subthreshold postsynaptic signal that summates with the signal initiated by the $20 \mathrm{~Hz}$ train. Thus, the temporal registry of trains from both cells is required for the "sharing" of plasticity between synapses.

We next examined the time course of heterosynaptic sharing and found that it decayed faster than PTP induced by the 20 $\mathrm{Hz}$ train (Fig. 1C). By 1 min after simultaneous activation, the EPSP associated with the $7 \mathrm{~Hz}$ train was no longer significantly different from baseline, while the corresponding $20 \mathrm{~Hz}$ EPSP was still significantly elevated at $10 \mathrm{~min}$. Next, to determine the temporal constraints on induction of heterosynaptic sharing, we varied the time between 7 and $20 \mathrm{~Hz}$ activation of the two SNs. Sharing was observed when the onset of trains was separated by $\leq 3 \mathrm{~s}$ (Fig. $1 D$ ) and was independent of the order of activation, indicating that the two SNs need not be coactive but that their activation must occur within a restricted time window. The symmetrical and relatively broad (3s) permissive time window for heterosynaptic sharing contrasts with previously described forms of associative plasticity such as spike timing-dependent plasticity and input timing-dependent plasticity, which have much more restricted temporal windows (in the range of milliseconds), and even for associative LTD in the cerebellum, in which pairing of inputs can occur on the order of hundreds of milliseconds (Sjöström and Nelson, 2002; Wang et al., 2003; Dan and Poo, 2004; Dudman et al., 2007; Sarkisov and Wang, 2008). This dissociation of temporal requirements suggests that heterosynaptic sharing represents a unique form of synaptic interaction whereby activity at one set of inputs can change the gain for local information flow at other synaptic sites.

\section{Heterosynaptic sharing requires postsynaptic $\mathrm{Ca}^{2+}$}

To examine the postsynaptic $\mathrm{Ca}^{2+}$ dependency of heterosynaptic sharing, we injected the $\mathrm{Ca}^{2+}$ chelator BAPTA into the MN, and 20 and $7 \mathrm{~Hz}$ trains of activation were delivered to two SNs. In contrast to the control condition, synaptic enhancement in the 7 $\mathrm{Hz} \mathrm{SN}$ was entirely blocked (Fig. $2 A$ ). We and others have previously shown that NMDA receptor activation is not required for induction of PTP at the SN-MN synapse (Schaffhausen et al., 2001; Jin and Hawkins, 2003). Moreover, Jin and Hawkins (2003) have previously shown that PTP in SN-MN cultures is dependent on intracellular $\mathrm{Ca}^{2+}$ release, but not on voltage-gated $\mathrm{Ca}^{2+}$ influx or extracellular $\mathrm{Ca}^{2+}$ concentration. Thus, we next examined the contribution of $\mathrm{Ca}^{2+}$ from intracellular stores. Perfusion of caffeine (which causes $\mathrm{Ca}^{2+}$ store depletion via the ryanodine receptor) and thapsigargin (a sarco/endoplasmic reticulum $\mathrm{Ca}^{2+}$ ATPase pump antagonist), as well as postsynaptic injection of heparin (an $\mathrm{IP}_{3} \mathrm{R}$ antagonist), also resulted in a total block of heterosynaptic sharing (Fig. $2 \mathrm{~A}$ ). Interestingly, although injection of heparin $(25 \mu \mathrm{M})$ completely blocked heterosynaptic sharing, this concentration had no effect on PTP. However, when we injected a higher concentration of heparin $(100 \mu \mathrm{M})$ we observed 
a significant attenuation of PTP (Fig. 2A), which is consistent with previous observations by Jin and Hawkins (2003), who also observed a significant attenuation of PTP in cultured SN-MNs by injecting this concentration of heparin into the MNs. The remaining PTP in the heparin $(100 \mu \mathrm{M})$ experiments (Fig. $2 A$ ) is likely due to the presynaptic contribution to PTP at these synapses (Schaffhausen et al., 2001).

While perfusion of thapsigargin and caffeine in the bath could affect both presynaptic and postsynaptic $\mathrm{Ca}^{2+}$, the block observed by these reagents, taken together with the block observed following injection of heparin into the $\mathrm{MN}$, are consistent with a possible role of $\mathrm{IP}_{3}$-mediated postsynaptic plasticity. To directly test this idea, we injected nondegradable $\mathrm{IP}_{3}$ into the MN. In this case, a $7 \mathrm{~Hz} \mathrm{SN}$ tetanus alone induced significant PTP (Fig. $2 B$ ). Collectively, these results suggest that effective $(20 \mathrm{~Hz}) \mathrm{SN}$ activation generates $\mathrm{IP}_{3}$-dependent release of $\mathrm{Ca}^{2+}$ from internal stores in the $\mathrm{MN}$, which facilitates the induction of sharing at the neighboring $(7 \mathrm{~Hz})$ synapse.

\section{Photolysis of caged $\mathrm{IP}_{3}$ induces $\mathrm{Ca}^{2+}$ transients in the MN neurites}

As demonstrated above, nondegradable $\mathrm{IP}_{3}-7 \mathrm{~Hz}$ pairing induces PTP (Fig. $2 B$ ). One potential mechanism that may account for this observation involves $\mathrm{IP}_{3}$ mediated $\mathrm{Ca}^{2+}$ release. To test this hypothesis, MNs were injected with Fluo-4 and caged $\mathrm{IP}_{3}$. As shown in Figure $3 A, B$, repetitive, localized $\mathrm{Ca}^{2+}$ transients in neurites were evoked by photorelease of $\mathrm{IP}_{3}$ following a UV flash. These observations are representative of results in four cells, obtained at 16 locations up to $500 \mu \mathrm{m}$ away from the cell body. These localized $\mathrm{Ca}^{2+}$ transients likely arise from clusters of $\mathrm{IP}_{3} \mathrm{Rs}$ and are reminiscent of puff activity as reported in mammalian cells (Smith et al., 2009).

\section{Heterosynaptic sharing is mimicked by pairing $7 \mathrm{~Hz}$ activation and photolysis of caged $\mathrm{IP}_{3}$}

To further elucidate the mechanisms of heterosynaptic sharing, we used the photolysis of caged $\mathrm{IP}_{3}$ to mimic the in situ generation of an $\mathrm{IP}_{3}$ signal induced by $20 \mathrm{~Hz}$ stimuli. We predicted that if $\mathrm{IP}_{3}$-mediated intracellular $\mathrm{Ca}^{2+}$ release is a critical component of the mechanism for sharing, then the transient $\mathrm{Ca}^{2+}$ release induced by the photoactivation of caged $\mathrm{IP}_{3}$ in the $\mathrm{MN}$, when paired with a train of subthreshold $7 \mathrm{~Hz}$ tetanus in the $\mathrm{SN}$, should mimic facilitation induced by heterosynaptic sharing. In SN-MN cocultures, MNs were injected with caged $\mathrm{IP}_{3}$ and the calcium indicator Fluo-4. A UV flash, which liberates free $\mathrm{IP}_{3}$ and induces calcium transients in the MN neurites (Fig. 3) was delivered to the MNs. We then examined the synaptic strengths at the SN-MN synapses before and after (1) a $20 \mathrm{~Hz}$ train, (2) a $7 \mathrm{~Hz}$ train, (3) a $7 \mathrm{~Hz}$ train paired with the photolysis of caged $\mathrm{IP}_{3},(4)$ photolysis alone, and (5) no stimulation (No Stim) (Fig. 4). We observed that the SN-MN synapses were significantly potentiated by $20 \mathrm{~Hz}$
B

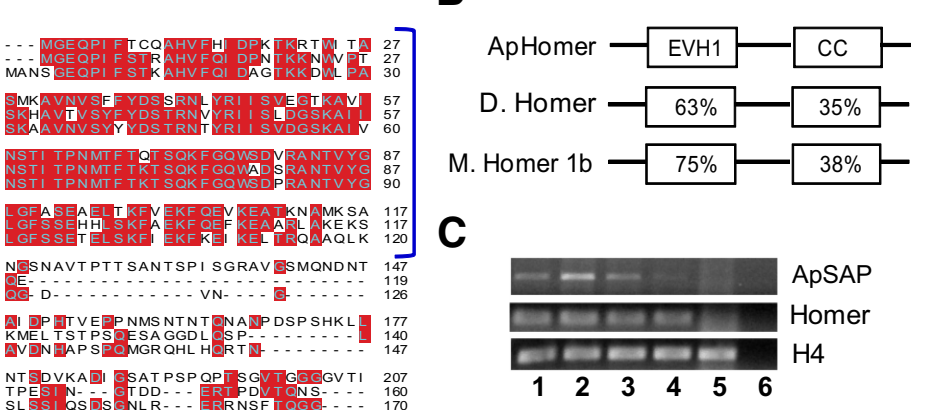

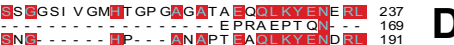

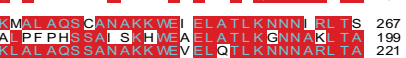

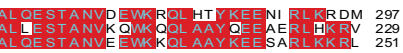

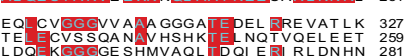
ARTEOL OKEL MORELE-LKS - E.-. KQEEI KRLNS QL QEVT - ARDT ON- - STLQQ 308

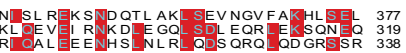

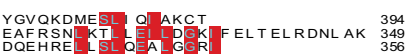
LLECS 356
394
354
356

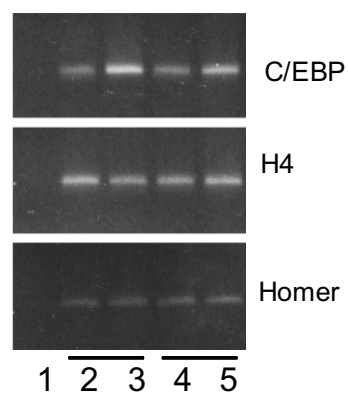

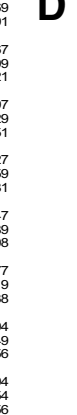

Figure 6. Identification of a Homer ortholog expressed in Aplysia. A, Amino acid sequence of ApHomer is shown in alignment with Drosophila Homer and mouse Homer 1b. Identical amino acids are shaded in red. The EVH1 region is bracketed in blue. The 列 with mouse and Drosophila Homers. Alignment within the EVH1 domain shows a particularly high degree of sequence identity as a rified as a biquitously expressed control. D, Semiquantitative RT-PCR of RNA from pleural and pedal ganglia. Lane 1, Water an in vivo 5-HT-treated animal; lane 4, cDNA prepared from RNA taken immediately from an anesthetized animal; lane 5, cDNA C/EBP levels are robustly increased. Similar results were observed following tailshock and $\mathrm{KCl}(100 \mathrm{~mm}$ ) depolarization (data not

stimuli alone (Fig. 4A,B). The significant potentiation exhibited following $20 \mathrm{~Hz}$ stimulation is all the more striking when compared with the No Stim control (Fig. 4B), which exhibited synaptic decrement typically observed in SN-MN cultured synapses (Eliot et al., 1994; Bao et al., 1997; Jin and Hawkins, 2003). Thus, the $20 \mathrm{~Hz}$-induced potentiation is superimposed on a progressively decrementing baseline [a similar result was previously observed by Jin and Hawkins (2003)]. SN-MNs exposed to either 7 $\mathrm{Hz}$ alone or photolysis alone also exhibited synaptic decrement that was comparable to the No Stim condition (Fig. $4 B$ ). In contrast, the pairing of $7 \mathrm{~Hz}$ stimuli and photolysis of caged $\mathrm{IP}_{3}$ induced significant synaptic potentiation (Fig. $4 A, B$ ). The facilitation induced by pairing $7 \mathrm{~Hz}$ with $\mathrm{IP}_{3}$ photolysis was significantly greater than that induced by the $7 \mathrm{~Hz}$ stimuli alone and was not significantly different from the facilitation induced by the 20 $\mathrm{Hz}$ stimuli alone (Fig. 4B). These data support the hypothesis that the postsynaptic intracellular $\mathrm{Ca}^{2+}$ transients induced by $\mathrm{IP}_{3}$ receptor activation are critically involved in heterosynaptic sharing.

\section{Molecular mechanisms of heterosynaptic sharing require postsynaptic Homer-mediated protein interactions}

We next explored the postsynaptic molecular mechanisms underlying sharing. Previous work by Jin and Hawkins (2003) indicated that mGluRs are required for PTP in cell culture. 
Thus, we examined the effects on monosynaptic PTP in pleural/pedal ganglia of two type I mGluR inhibitors, LY367385 and S-MCPG. While control synapses demonstrated robust PTP, both LY367385 and S-MCPG caused a significant attenuation of PTP, with no effect on baseline synaptic transmission (Fig. $5 A, B)$. The remaining PTP observed in the presence of inhibitors is likely due to the presynaptic component of PTP at these synapses (Schaffhausen et al., 2001).

Given the $\mathrm{mGluR} / \mathrm{Ca}^{2+}$ dependency and $\mathrm{IP}_{3}$ involvement in sharing, an attractive molecular candidate for mediating PTP and heterosynaptic sharing was Homer, a well described protein in the vertebrate postsynaptic density. Homer proteins mediate a series of interactions with other proteins including mGluRs as well as $\mathrm{IP}_{3}$ receptors (Tu et al., 1998; Worley et al., 2007). Moreover, Homer proteins have been demonstrated both to couple mGluR signaling with intracellular $\mathrm{Ca}^{2+}$ release in vertebrate neurons (Tu et al., 1998) and to localize $\mathrm{IP}_{3} \mathrm{Rs}$ within dendritic subregions, allowing for synaptically localized $\mathrm{IP}_{3}$-mediated $\mathrm{Ca}^{2+}$ release (Sala et al., 2001, 2005). However, there was no available evidence to indicate that a Homer ortholog is expressed in Aplysia, or whether it might play a role in the spread of plasticity.

Thus, to directly explore the possible involvement of Homer in sharing, we first cloned Aplysia Homer (ApHomer) using a combination of degenerate RT-PCR and library screening (Fig. $6 A, B)$. ApHomer shares the domain organization of other Homer proteins, including an N-terminal EVH1 domain and a C-terminal coiled-coil region. In vertebrates, Homer has been predominantly studied in the nervous system but is also expressed in tissues outside the CNS, as observed for ApHomer (Fig. 6C). In comparison, the gene for Aplysia MAGUK protein ApSAP is expressed predominantly within the CNS (Reissner et al., 2008). Because Homer was first identified as an activitydependent immediate early gene (Brakeman et al., 1997; Kato et al., 1997), we used semiquantitative RT-PCR to assess message levels in response to injury, in vivo 5- $\mathrm{HT}, \mathrm{KCl}$ depolarization, or tailshock (which induces behavioral sensitization). None of these treatments induced a significant change in the cDNA levels of histone $\mathrm{H} 4$ or Homer but did induce a substantial increase in a positive control, C/EBP (Fig. 6D). These findings thus indicate the lack of an activity-dependent splice variant of Homer and suggest that there is no change in the amount of the constitutively expressed splice form of Homer following experience. These results are consistent with findings in Drosophila, where there appears to be only one gene and one transcript for Homer (Diagana et al., 2002). However, we did identify an alternative splice variant at the extreme $5^{\prime}$ end of the mRNA, which would translate into proteins differing among the first six amino acids (supplemental Fig. 1, available at www.jneurosci.org as supplemental material).

A prerequisite for our hypothesis that ApHomer has a mechanistic role in heterosynaptic sharing is that Homer-mediated interactions observed in vertebrates, particularly with mGluRs and $\mathrm{IP}_{3} \mathrm{Rs}$, should be conserved in Aplysia. We found that recombinant ApHomer could successfully coprecipitate rat mGluR $1 \alpha$ in a GST pull-down experiment (Fig. 7). However, a low signalto-noise ratio result made it difficult to interpret pull-down results for $\mathrm{IP}_{3} \mathrm{R}$ (Fig. 7, bottom right). To directly examine a possible interaction between ApHomer and Aplysia $\mathrm{IP}_{3} \mathrm{R}$, we determined the coding sequence for the initial 154 aa of $\mathrm{ApIP}_{3} \mathrm{R}$. A cDNA for Aplysia $\mathrm{IP}_{3} \mathrm{R}$ has also been reported, matching the sequences we obtained (Cummins et al., 2007). The consensus sequence for Homer binding is PXXFr (Tu et al., 1998), and in rat $\mathrm{IP}_{3} \mathrm{R}$ it is found at amino acid positions $49-54$. This sequence is

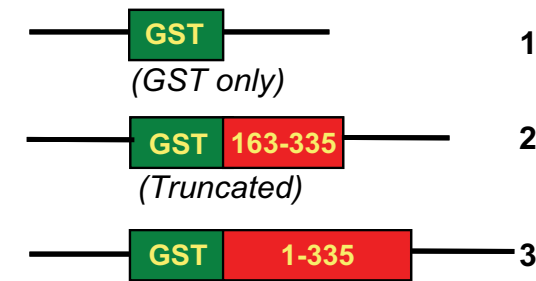

(Full-length)

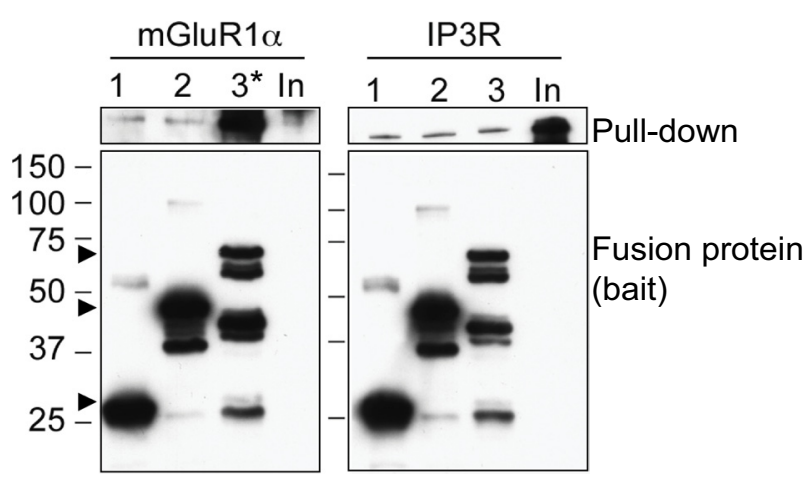

Figure 7. ApHomer coprecipitates rat mGluR $1 \alpha$. Top, GST (1) or GST fusion proteins with either amino acids 163-335 (2) or the first 335 aa of ApHomer (3) were bacterially expressed and purified for a GST pull-down with rat cerebellar extract. Bottom, Western blot for mGluR1 $\alpha$ and $I_{3} R$ of pull-downs. Lane numbers represent the matching number beside constructs used as bait. In, input. Full-length GST-ApHomer coprecipitates mGluR1 $\alpha$ (Western blot: left panel, upper portion, lane 3), whereas GST alone (lane 1) and a GST fusion protein containing the (-terminal portion of ApHomer (lane 2) do not. In contrast, an interaction between ApHomer and rat $I_{3} R$ could not be conclusively demonstrated due to a nonspecific signal observed between all constructs and $I P_{3} R$. Top, Left and right, shows Western blot for mGluR1 and $I P_{3} R$, whereas bottom, left and right, shows the same blots stripped and reprobed with an anti-GST antibody. The presence of GST or GST fusion proteins is indicated by arrowheads at left.

100\% conserved between Aplysia and other vertebrates and invertebrates (Fig. $8 A$ ).

The first 256 aa of $\mathrm{ApIP}_{3} \mathrm{R}$ were expressed as a GST fusion protein for a pull-down assay, as described above. A custom antibody was generated against ApHomer amino acids 324-344, which resulted in immunoreactivity against multiple bands in Aplysia CNS extract (Fig. 8B, lane 1). However, Western blot following the GST pull-down assay indicated that, while the antiApHomer antibody recognizes a complex series of bands in CNS extract used as input, only a single band of $\sim 47 \mathrm{kDa}$ is observed in samples eluted from beads coupled to GST-ApIP ${ }_{3} \mathrm{R}$ (Fig. $8 B$, lanes 3-6). This is in agreement with the $\sim 45-50 \mathrm{kDa}$ size of mammalian and Drosophila Homers and the expected size of ApHomer. Moreover, inclusion of a 12 amino acid peptide matching the Homer recognition sequence within $\mathrm{ApIP}_{3} \mathrm{R}$ competed away this interaction in a concentration-dependent manner, whereas a mutant peptide had no effect (Fig. $8 B$ ).

The synthetic peptide used to inhibit the $\mathrm{ApIP}_{3} \mathrm{R}-\mathrm{ApHomer}$ interaction in vitro now provided a powerful experimental tool to directly explore Homer-mediated $\mathrm{IP}_{3}$ activation in sharing. We pressure injected MNs with either the $\mathrm{ApIP}_{3} \mathrm{R}$ peptide or mutant peptide, in which two critical amino acids in the Homer-binding sequence were substituted. One hour postinjection, two SNs were activated with either 20 or $7 \mathrm{~Hz}$ to explore PTP and sharing (Fig. $8 C$ ). Following injection of the mutant peptide, $20 \mathrm{~Hz}$ activation induced significant PTP, and simultaneous $7 \mathrm{~Hz}$ activation induced significant heterosynaptic sharing. In contrast, following injection of the $\mathrm{ApIP}_{3} \mathrm{R}$ peptide into the $\mathrm{MN}$, the $20 \mathrm{~Hz}$ PTP was reduced, indicating a partial block by the active peptide, which is 
consistent with our previous observation that $20 \mathrm{~Hz}$ PTP has both presynaptic and postsynaptic components (Fig. 5) (see also, Schaffhausen et al., 2001). Importantly, heterosynaptic sharing induced by simultaneous activation with $7 \mathrm{~Hz}$ was completely blocked. No effect was observed on baseline synaptic transmission. Finally, the attenuation of PTP and block of sharing by the peptide was restricted to short-term, activity-dependent plasticity at the SN-MN synapse. Short-term facilitation induced by a single pulse of 5-HT was unaffected by the peptide (supplemental Fig. 2, available at www.jneurosci. org as supplemental material).

\section{Discussion}

Our results elucidate a series of molecular steps that provide a mechanism through which short-term plasticity may be shared between two neighboring synapses. Collectively, our findings support the hypothesis that low-level (e.g., $7 \mathrm{~Hz}$ ) activation of an $\mathrm{SN}$ alone leads to postsynaptic release of $\mathrm{IP}_{3}$, which is subthreshold for the induction of PTP, but can summate with $\mathrm{IP}_{3}$ liberated by high-level activation (e.g., 20 $\mathrm{Hz}$ ) of another presynaptic input (Fig. 9). The idea that $\mathrm{IP}_{3}$ summation can result in molecular integration has been previously suggested by Parker and colleagues, who found that caged $\mathrm{IP}_{3}$ responses can summate at distances up to $20 \mu \mathrm{m}$ (Parker, 1989; Parker and Miledi, 1989; Parker and Ivorra, 1992). SN-MN synapses in Aplysia commingle with intersynaptic distances in many cases well within this $20 \mu \mathrm{m}$ range (Marinesco and Carew, 2002), supporting the idea that subthreshold $\mathrm{IP}_{3}$ released in the postsynaptic neuron by low-level activation may summate with additional $\mathrm{IP}_{3}$ from high-level input to generate a form of molecular coincidence detection that induces a sufficient $\mathrm{Ca}^{2+}$ signal to give rise to heterosynaptic sharing.

In the long-term time domain (e.g., LTP and LTD), $\mathrm{Ca}^{2+}$ dependent heterosynaptic expansion of synaptic plasticity has been observed in other systems (Nishiyama et al., 2000; Royer and Pare, 2003). In addition, communication between proximal hippocampal CA1 synapses has been revealed by facilitation of LTP at a minimally activated synapse following LTP induction at a nearby synapse (Harvey and Svoboda, 2007). However, the heterosynaptic amplification of hippocampal LTP is not dependent on intracellular $\mathrm{Ca}^{2+}$, whereas the heterosynaptic sharing we observe requires a postsynaptic $\mathrm{Ca}^{2+}$ response coupled to Homer- and $\mathrm{IP}_{3} \mathrm{R}$-dependent protein-protein interactions.

The current study raises two important questions regarding $\mathrm{Ca}^{2+}$ signaling. First, how might postsynaptic $\mathrm{Ca}^{2+}$ mediate the induction of PTP at strongly activated synapses, and second, how might postsynaptic $\mathrm{Ca}^{2+}$ contribute to heterosynaptic sharing at weakly activated synapses? Considering the first question, one candidate mechanism for the induction of PTP at strongly activated synaptic sites is CaMKII, since it is well established that $\mathrm{Ca}^{2+}$-dependent kinases can be critical mediators of synaptic plasticity. For example, CaMKII regulates the conductance of

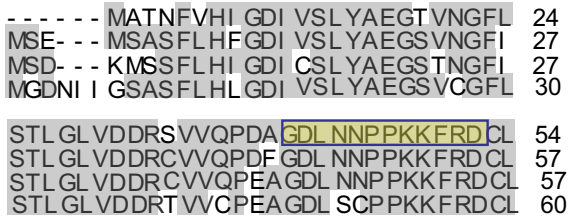

STL GL VDDRT VCPEA GDL SCPPKKFRDCL 60

然

B $\quad 0 \quad 0.21 .0 \quad 0$ peptide $(\mathrm{mM})$ \begin{tabular}{lllll}
0 & 0 & 0 & 1.0 & MUT pep $(\mathrm{mM})$ \\
\hline
\end{tabular}

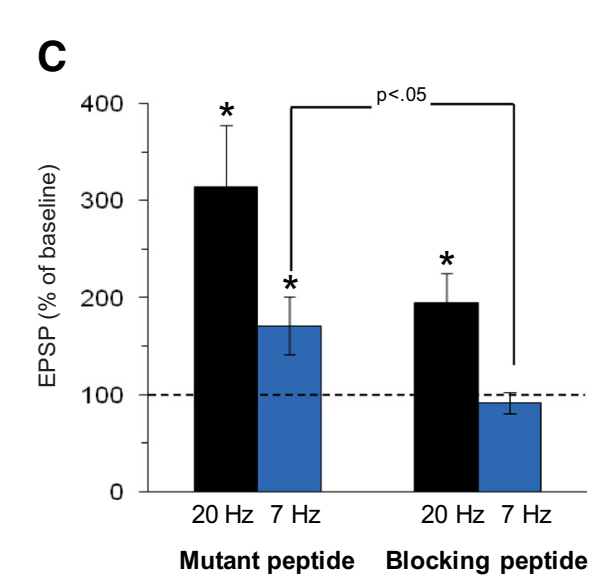




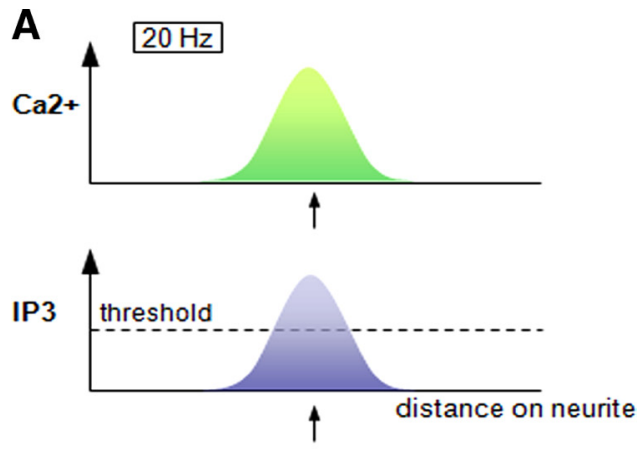

B

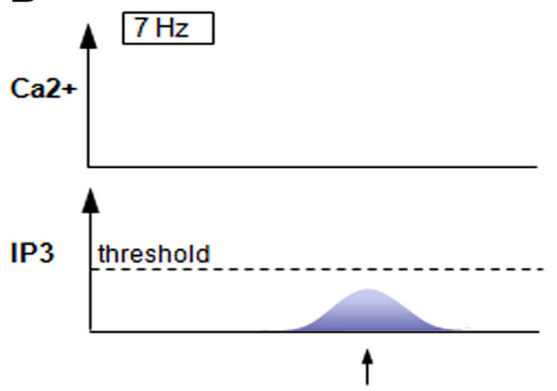

C $20+7 \mathrm{~Hz}$
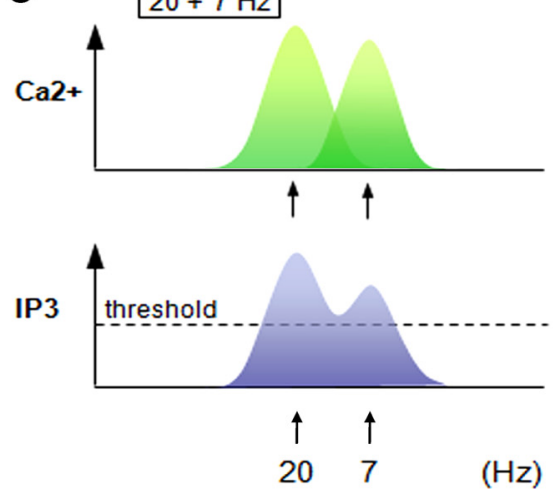

Figure 9. Molecular model for sharing of short-term synaptic plasticity. Model for molecular coincidence detection: dotted line represents $\mathbb{I P}_{3}$ threshold for intracellular $\mathrm{Ca}^{2+}$ release sufficient to induce PTP. Abscissa indicates $\mathrm{Ca}^{2+} / \mathrm{PP}_{3}$ spread within a neurite. $A, 20 \mathrm{~Hz}$ delivered to an $\mathrm{SN}$ is sufficient for local threshold $\mathrm{IP}_{3}$ generation (blue), thus leading to intracellular $\mathrm{Ca}^{2+}$ release (green). $\boldsymbol{B}$, However, $7 \mathrm{~Hz}$ alone does not achieve the $\mathrm{IP}_{3}$ threshold required for $\mathrm{Ca}^{2+}$ release. $\boldsymbol{C}$, In contrast, when neighboring synapses are coactivated at 7 and $20 \mathrm{~Hz}$ within a narrow temporal window, summation of local $\mathrm{IP}_{3}$ signals surpass the threshold for $\mathrm{Ca}^{2+}$ release and thus give rise to potentiation of the $7 \mathrm{~Hz} S \mathrm{~N}$ synapse, resulting in sharing of synaptic enhancement.

spines (Harvey et al., 2008), making it also an attractive candidate for mediating signaling contributing to PTP sharing. Thus, a number of interactive $\mathrm{Ca}^{2+}$-dependent postsynaptic signaling events may contribute both to the initial induction of PTP as well the sharing of PTP that we observe.

Our data also indicate that ApHomer-mediated protein interactions are critical for heterosynaptic sharing, since the synthetic peptide that interrupts Homer- $\mathrm{IP}_{3} \mathrm{R}$ interactions completely blocks sharing. Interestingly, injection of the $\mathrm{ApIP}_{3} \mathrm{R}$ peptide into the MN also tends to reduce the level of PTP (although not to a level that reaches statistical significance), suggesting that, as in the case of heparin, blockade of the signaling pathway between Homer and intracellular $\mathrm{Ca}^{2+}$ release is more readily impaired in the case of heterosynaptic sharing compared with PTP. Another difference between heterosynaptic sharing and PTP is their time course. Sharing is significantly attenuated after $60 \mathrm{~s}$, whereas PTP lasts $>10$ min. Thus, although not conclusive, the differential sensitivity of heterosynaptic sharing and PTP to both heparin concentration and the $\mathrm{ApIP}_{3} \mathrm{R}$ peptide, taken together with their differential time courses, suggests that these two forms of synaptic plasticity are not mechanistically identical.

What are the mechanisms by which disruption of Homermediated interactions might inhibit induction of PTP and heterosynaptic sharing? An obvious candidate is postsynaptic $\mathrm{Ca}^{2+}$ release at the activated synapse, localized by a protein scaffold linking type I mGluRs, Homer, and $\mathrm{IP}_{3}$ Rs. However, since the conserved Homer binding sequence is present in additional Homer ligands, these interactions are also likely to be disrupted by the synthetic peptide as well. For example, a number of Homer ligands containing the PXXFr sequence have been identified, including the Ryanodine receptor Shank, Dynamin III, PI3 kinase enhancer, and transient receptor potential cation channels (Tu et al., 1998; Feng et al., 2002; Rong et al., 2003; Yuan et al., 2003; Lu et al., 2007). These interactions serve to regulate release of $\mathrm{Ca}^{2+}$ from intracellular stores, activation of PI3 kinase, maturation of dendritic spines, as well as the localization of synaptic AMPA receptors and modulation of synaptic strength (Sala et al., 2001; Rong et al., 2003; Sala et al., 2005; Lu et al., 2007). Although our results support a model in which mGluR-Homer- $\mathrm{IP}_{3} \mathrm{R}$ interactions mediate a local $\mathrm{Ca}^{2+}$ signal near activated synapses, which may travel to nearby synapses as part of the mechanism of sharing (Fig. 9), we cannot rule out other Homer-dependent mechanistic components to heterosynaptic sharing.

Finally, an intriguing question arises from the present work. What is the functional significance of heterosynaptic sharing? The SN-MN synapses examined in this study mediate the monosynaptic component of the tail-elicited tail withdrawal reflex in Aplysia, in which a tactile stimulus to the tail gives rise to the withdrawal of the tail from the site of stimulation. Because there is an approximate topographic arrangement of $\mathrm{SN}$-mediated tactile input from the tail skin onto the tail MNs (Walters et al., 2004), the sharing of plasticity we observe could allow the animal to be transiently more responsive to a weak stimulus applied to a neighboring area on the tail where a strong stimulus recently occurred. This enhancement of sensitivity within the net receptive field of the reflex would be constrained to a restricted time window commensurate with the duration of the net plasticity induced at neighboring SN presynaptic inputs to the tail MNs. In this fashion, the functional tactile receptive field of the reflex would be dynamically and rapidly expanded following a focal strong stimulus to the tail, with a time course sufficient for the animal to make an integrated, adaptive behavioral response.

In principle, one could expand this general notion to any site in a neural network where there is convergent presynaptic input onto a common postsynaptic target. At these convergent sites, heterosynaptic sharing of short-term plasticity could provide a potential mechanism for the time-limited rapid and dynamic expansion of the functional "receptive field" of a postsynaptic neuron. From this perspective, inputs whose activation are below threshold for the induction of plasticity can, by virtue of temporal coincidence with other suprathreshold inputs, subsequently acquire plasticity and thus more effectively drive the postsynaptic target. In this fashion, the net enhanced synaptic input onto the postsynaptic neuron is dynamically expanded within a constrained time course dictated by the duration of the composite plasticity at those presynaptic sites. This general mechanism could allow for a novel form of integration in a neural network by providing a means of rapid and transient sharing of plasticity 
arising from temporally correlated inputs to a common postsynaptic target.

\section{References}

Alberini CM, Ghirardi M, Metz R, Kandel ER (1994) C/EBP is an immediate-early gene required for the consolidation of long-term facilitation in Aplysia. Cell 76:1099-1114.

Bao JX, Kandel ER, Hawkins RD (1997) Involvement of pre- and postsynaptic mechanisms in posttetanic potentiation at Aplysia synapses. Science 275:969-973.

Boehm J, Malinow R (2005) AMPA receptor phosphorylation during synaptic plasticity. Biochem Soc Trans 33:1354-1356.

Brakeman PR, Lanahan AA, O'Brien R, Roche K, Barnes CA, Huganir RL, Worley PF (1997) Homer: a protein that selectively binds metabotropic glutamate receptors. Nature 386:284-288.

Bredt DS, Nicoll RA (2003) AMPA receptor trafficking at excitatory synapses. Neuron 40:361-379.

Cummins SF, De Vries MR, Hill KS, Boehning D, Nagle GT (2007) Gene identification and evidence for expression of $\mathrm{G}$ protein alpha subunits, phospholipase C, and an inositol 1,4,5-trisphosphate receptor in Aplysia californica rhinophore. Genomics 90:110-120.

Dan Y, Poo MM (2004) Spike timing-dependent plasticity of neural circuits. Neuron 44:23-30.

Diagana TT, Thomas U, Prokopenko SN, Xiao B, Worley PF, Thomas JB (2002) Mutation of Drosophila homer disrupts control of locomotor activity and behavioral plasticity. J Neurosci 22:428-436.

Dudman JT, Tsay D, Siegelbaum SA (2007) A role for synaptic inputs at distal dendrites: instructive signals for hippocampal long-term plasticity. Neuron 56:866-879.

Eliot LS, Hawkins RD, Kandel ER, Schacher S (1994) Pairing-specific, activity-dependent presynaptic facilitation at Aplysia sensory-motor neuron synapses in isolated cell culture. J Neurosci 14:368-383.

Feng W, Tu J, Yang T, Vernon PS, Allen PD, Worley PF, Pessah IN (2002) Homer regulates gain of ryanodine receptor type 1 channel complex. J Biol Chem 277:44722-44730.

Garaschuk O, Yaari Y, Konnerth A (1997) Release and sequestration of calcium by ryanodine-sensitive stores in rat hippocampal neurones. J Physiol 502:13-30.

Gruenbaum LM, Carew TJ (1999) Growth factor modulation of substratespecific morphological patterns in Aplysia bag cell neurons. Learn Mem 6:292-306.

Harvey CD, Svoboda K (2007) Locally dynamic synaptic learning rules in pyramidal neuron dendrites. Nature 450:1195-1200.

Harvey CD, Yasuda R, Zhong H, Svoboda K (2008) The spread of Ras activity triggered by activation of a single dendritic spine. Science 321:136-140.

Hong M, Ross WN (2007) Priming of intracellular calcium stores in rat CA1 pyramidal neurons. J Physiol 584:75-87.

Jin I, Hawkins RD (2003) Presynaptic and postsynaptic mechanisms of a novel form of homosynaptic potentiation at Aplysia sensory-motor neuron synapses. J Neurosci 23:7288-7297.

Kato A, Ozawa F, Saitoh Y, Hirai K, Inokuchi K (1997) vesl, a gene encoding VASP/Ena family related protein, is upregulated during seizure, longterm potentiation and synaptogenesis. FEBS Lett 412:183-189.

Leissring MA, Parker I, LaFerla FM (1999) Presenilin-2 mutations modulate amplitude and kinetics of inositol 1,4,5-trisphosphate-mediated calcium signals. J Biol Chem 274:32535-32538.

Lu J, Helton TD, Blanpied TA, Rácz B, Newpher TM, Weinberg RJ, Ehlers MD (2007) Postsynaptic positioning of endocytic zones and AMPA receptor cycling by physical coupling of dynamin-3 to Homer. Neuron 55:874-889.

Lyles V, Zhao Y, Martin KC (2006) Synapse formation and mRNA localization in cultured Aplysia neurons. Neuron 49:349-356.

Malenka RC (2003) Synaptic plasticity and AMPA receptor trafficking. Ann N Y Acad Sci 1003:1-11.

Malkinson G, Spira ME (2010) Imaging and analysis of evoked excitatorypostsynaptic-calcium-transients by individual presynaptic-boutons of cultured Aplysia sensorimotor synapse. Cell Calcium 47:315-325.
Marinesco S, Carew TJ (2002) Serotonin release evoked by tail nerve stimulation in the CNS of Aplysia: characterization and relationship to heterosynaptic plasticity. J Neurosci 22:2299-2312.

Nishiyama M, Hong K, Mikoshiba K, Poo MM, Kato K (2000) Calcium stores regulate the polarity and input specificity of synaptic modification. Nature 408:584-588.

Parker I (1989) Latency, threshold and facilitation in phosphoinositide signalling. In: Membrane technology (Verna R, ed), pp 39-56. New York: Raven.

Parker I, Ivorra I (1992) Characteristics of membrane currents evoked by photoreleased inositol trisphosphate in Xenopus oocytes. Am J Physiol 263:C154-C165.

Parker I, Miledi R (1989) Nonlinearity and facilitation in phosphoinositide signaling studied by the use of caged inositol trisphosphate in Xenopus oocytes. J Neurosci 9:4068-4077.

Reissner KJ, Boyle HD, Ye X, Carew TJ (2008) Aplysia synapse associated protein (APSAP): identification, characterization, and selective interactions with Shaker-type potassium channels. J Neurochem 105:10061018.

Rong R, Ahn JY, Huang H, Nagata E, Kalman D, Kapp JA, Tu J, Worley PF, Snyder SH, Ye K (2003) PI3 kinase enhancer-Homer complex couples mGluRI to PI3 kinase, preventing neuronal apoptosis. Nat Neurosci 6:1153-1161.

Royer S, Paré D (2003) Conservation of total synaptic weight through balanced synaptic depression and potentiation. Nature 422:518-522.

Sala C, Piëch V, Wilson NR, Passafaro M, Liu G, Sheng M (2001) Regulation of dendritic spine morphology and synaptic function by Shank and Homer. Neuron 31:115-130.

Sala C, Roussignol G, Meldolesi J, Fagni L (2005) Key role of the postsynaptic density scaffold proteins Shank and Homer in the functional architecture of $\mathrm{Ca}^{2+}$ homeostasis at dendritic spines in hippocampal neurons. J Neurosci 25:4587-4592.

Sarkisov DV, Wang SS (2008) Order-dependent coincidence detection in cerebellar Purkinje neurons at the inositol trisphosphate receptor. J Neurosci 28:133-142.

Schaffhausen JH, Fischer TM, Carew TJ (2001) Contribution of postsynaptic $\mathrm{Ca}^{2+}$ to the induction of post-tetanic potentiation in the neural circuit for siphon withdrawal in Aplysia. J Neurosci 21:1739-1749.

Sharma SK, Sherff CM, Shobe J, Bagnall MW, Sutton MA, Carew TJ (2003) Differential role of mitogen-activated protein kinase in three distinct phases of memory for sensitization in Aplysia. J Neurosci 23:3899-3907.

Sjöström PJ, Nelson SB (2002) Spike timing, calcium signals and synaptic plasticity. Curr Opin Neurobiol 12:305-314.

Smith IF, Wiltgen SM, Parker I (2009) Localization of puff sites adjacent to the plasma membrane: functional and spatial characterization of $\mathrm{Ca}^{2+}$ signaling in SH-SY5Y cells utilizing membrane-permeant caged IP3. Cell Calcium 45:65-76.

Tu JC, Xiao B, Yuan JP, Lanahan AA, Leoffert K, Li M, Linden DJ, Worley PF (1998) Homer binds a novel proline-rich motif and links group 1 metabotropic glutamate receptors with IP3 receptors. Neuron 21:717726.

Walters ET, Bodnarova M, Billy AJ, Dulin MF, Díaz-Ríos M, Miller MW, Moroz LL (2004) Somatotopic organization and functional properties of mechanosensory neurons expressing sensorin-A mRNA in Aplysia californica. J Comp Neurol 471:219-240.

Wang Z, Xu NL, Wu CP, Duan S, Poo MM (2003) Bidirectional changes in spatial dendritic integration accompanying long-term synaptic modifications. Neuron 37:463-472.

Worley PF, Zeng W, Huang G, Kim JY, Shin DM, Kim MS, Yuan JP, Kiselyov $\mathrm{K}$, Muallem S (2007) Homer proteins in $\mathrm{Ca}^{2+}$ signaling by excitable and non-excitable cells. Cell Calcium 42:363-371.

Yuan JP, Kiselyov K, Shin DM, Chen J, Shcheynikov N, Kang SH, Dehoff MH, Schwarz MK, Seeburg PH, Muallem S, Worley PF (2003) Homer binds TRPC family channels and is required for gating of TRPC1 by IP3 receptors. Cell 114:777-789.

Zucker RS, Regehr WG (2002) Short-term synaptic plasticity. Annu Rev Physiol 64:355-405. 